\section{Rescued sea otters fly the coup}

\section{San Francisco}

INITIAL radio transmitter data from the $\mathbf{1 9 3}$ captured sea otters which were released into Prince William Sound late last month have held several surprises for marine biologists tracking the mammals. The otters had earlier been rescued from the giant Alaskan oil spill.

Despite rough weather that disrupted signals, researchers have stayed in touch with the 45 otters carrying surgically implanted radio-transmitters. All were released north of Cordova, in the eastern part of Prince William Sound and away from the devastating effects of the March spill of some 10 million gallons of crude oil. The slick drifted west into the Kenai Peninsula area, where most of the captured otters were rescued.

So far, however, it seems that none of the otters has returned home. "Our best information is that the otters are all still in the sound", says Tony DeGange, a wildlife biologist with the US Fish and Wildlife Service.

They were thought likely to move back to the Kenai, where they were caught. But most have dispersed from the release point, and a few have already travelled several hundred kilometres.

Wandering is expected, especially among females, which have large seasonal movements compared to the more territorial males.

Researchers next plan to install radiotags on other otters that remained free

$$
\begin{aligned}
& \text { They must be looking for an } \\
& \text { Exxon representative... }
\end{aligned}
$$

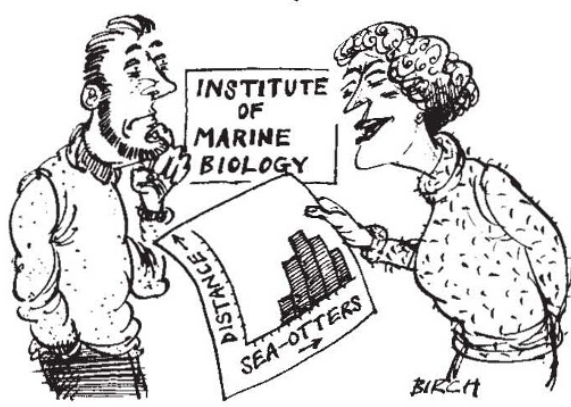

throughout the crisis. Some will come from the oil-spill zone, the remainder will be a control group from untainted eastern waters. The idea is to "validate the whole rehabilitation process", says DeGange, and to see if the otters that were treated and released "become full-functioning members of the sea otter community again". The free-ranging otters from the spill area will be compared with the control group to see if reseachers can detect any effects - in survival and reproductive rates - of living in the oil zone.

Robert Buderi

\title{
Slimming down for sell-off
}

\section{London}

THE United Kingdom Atomic Energy Authority (AEA) is to undergo a rigorous rationalization programme aimed at attracting finance from the private sector after a series of cuts in government funding. The authority will split its business activities into nine discrete areas, each covering a sector of research which is considered commercially viable. John Collier, chairman of AEA, revealed last week that nine chief executives would head the subsidiaries independently under the authority's new commercial banner, AEA Technology.

The nine business areas are the fast reactor, fusion technology, nuclear fuel cycle technology, environmental protection services, thermal reactors, contract research, oil and gas, risk management technology and decommisioning and radioactive waste management.

The AEA had incurred inevitable restructuring costs and had to reduce manpower to fit estimated future turnover and compensate for the reduced government contribution to research into the fast EARTH SCIENCES

\section{Germans to drill to $10 \mathrm{~km}$}

\section{Munich}

THE West German government announced last week that it will continue to pour money down a hole in northern Bavaria. The money, DM500 million in all ( $\$ 256$ million), is to be spent on what was meant to be the deepest hole in the world. Now the hole will go only $10 \mathrm{~km}$ down, but it will still give geologists a glimpse of an unexplored part of the Earth's crust.

The decision to go ahead with the project, officially known as the "Continental Deep-Drilling" project (KTB in German), was based in large part on the success of a 4,001-metre-deep pilot hole drilled near the Bavarian town of Windischeschenbach. Researchers will begin drilling the deeper hole in August 1990. They hope to complete it in 1994.

The West German geology community strongly supports KTB, which, along with the Soviet deep hole on the Kola Peninsula, is one of the most ambitious deepdrilling projects in the world. The West German Research Ministry (BMFT) has also been generous in its support for KTB. The latest budget includes an increase of DM50 million above the original figures. But a BMFT spokesman stressed that the ministry was backing KTB entirely for scientific reasons, and not, as some have speculated, because of the good publicity the project has been generating.

Plans to drill to $14 \mathrm{~km}$ had to be abandoned when the pilot hole encoun- reactor, according to Collier. These costs, with a $£ 27$ million provision for the future, left the authority with a current loss of $£ 41$ million for 1988-89.

Collier criticized government cuts in support for the fast reactor and energy research programmes. "To be serious about nuclear power requires us also to be serious about the fast reactor", he said. The government has also warned that it plans to cut support for the Dounreay fast reactor and fusion work at Culham.

But Collier introduced a note of optimism when he revealed that the authority had signed a series of agreements in Bonn to ensure British involvement in the future of European research into fast reactors. He said the deal provided a "sound basis" for the AEA to move to the "demonstration phase" of fast reactor development with partners in France and West Germany.

"The European collaboration is the best and perhaps only way for the UK to ensure fast reactors are available when we need them early next century", he said.

Ben Webb tered the unexpectedly high temperature of $118^{\circ} \mathrm{C}$ at $3.5 \mathrm{~km}$. The temperature will probably climb to the functional limit of the equipment $-300^{\circ} \mathrm{C}$ - by the time the hole reaches $10 \mathrm{~km}$. If it is less hot, the researchers will decide in 1993 if they want to try to drill down to $12 \mathrm{~km}$. Ironically, the drilling site was chosen because the crust was expected to be cooler than at other sites in West Germany.

And there have been other surprises. The cores brought up from $3 \mathrm{~km}$ were under extreme stresses that researchers had expected to find only at $7 \mathrm{~km}$ or deeper. At $3.4 \mathrm{~km}$, the drill-bit hit fissures filled with salty brine that may be a remnant of primordial oceans.

Below $3.2 \mathrm{~km}$, large amounts of helium and methane were found. The methane may derive from the crust itself, rather than organic matter on the surface, lending support to those, such as astronomer Thomas Gold, who claim that natural gas can be found in the crust. Gold has led a deep-drilling project in Sweden intended to find useful amounts of methane gas in crystalline rock, where it has never been found before.

The KTB team has also made advances in drilling technology. For instance, they have developed a special 'drilling mud' a colloidal silicate pumped into the hole to lubricate the rotating diamond drill-bit which oozes up the hole, shoring up the walls.
Steven Dickman 